\title{
PERFORMANCE EVALUATION OF SELECTED GROWTH - ORIENTED MUTUAL FUNDS
}

* SATHYA SWAROOP DEBASISH

\&

** NIKHIL CHANDRA SHIL (Corresponding Author)

\begin{abstract}
In the backdrop of liberalization and private participation in the Indian mutual fund industry, the challenge to survive and retain investors' confidence has been a prime concern for fund managers. For small investors who do not have the time or the expertise to take direct investment decision in equities successfully, the alternative is to invest in mutual funds. Performance of the mutual fund products become more complex in the context of accommodating both return and risk measurements while giving due importance to investment objectives. In this paper, an attempt has been made to study the performance of selected schemes of mutual funds based on risk-return relationship models and measures. A total of 23 schemes offered by six private sector mutual funds and three public sector mutual funds have beer studied over the time period from April 1996 to March 2009 (thirteen years). The analysis has been made on the basis of mean return, beta risk, coefficient of determination, Sharpe ratio, Treynor ratio and Jensen Alpha. The overall analysis finds Franklin Templeton and UTI being the best performers, and Birla SunLife, HDFC and LIC mutual funds showing poor below-average performance when measured against the risk-return relationship models.
\end{abstract}

Keywords: Mutual Fund, Sharpe Ratio, Treynor ratio, Beta, Jensen Alpha.

\section{Introduction}

Growth and developments of various mutual funds products in Indian capital market has proved to be one of the most catalytic instruments in generating momentous investment growth in the capital market. In this context, close monitoring and evaluation of mutual funds has become essential. With emphasis on increase in domestic savings and improvement in deployment of investment through markets, the need and scope for mutual fund operation has increased tremendously. Thus the involvement of mutual funds in the transformation of Indian economy has made it urgent to view their services not only as financial intermediary but also as pace setter as they are playing a significant role in spreading equity culture.

Mutual Fund is one of the most preferred investment alternatives for the small investors as it offers an opportunity to invest in a diversified, professionally managed portfolio at a relatively low cost. A Mutual Fund is a trust that pools the savings of a number of investors who share a common financial goal. Over the past decade, mutual funds have increasingly become the investor's vehicle of choice for longterm investing.

* P. G. Department of Business Management, Fakir Mohan University, Balasore, Orissa 756019, India E-mail: sathyaswaroop2000@yahoo.com

** P.G.Department of Business Administration, East West University, 43, Mohakhali C/A, Dhaka - 1212, Bangladesh, Email: nikhilacc @ yahoo.com 
The Indian mutual fund industry has a total corpus of over Rs 700 billion collected from more than 20 million investors. The largest category of mutual funds are those of Unit Trust of India (UTI), followed by ones floated by nationalized banks (like SBI) and the third largest category of mutual funds are the ones floated by the private sector and by foreign asset management companies (like Prudential ICICI and Birla SunLife ). In recent times, the important trend in the mutual fund industry is the aggressive expansion of the foreign owned mutual fund companies and the decline of the companies floated by nationalized banks and smaller private sector players.

In this context, it becomes pertinent to study the performance of Indian mutual fund industry. The relation between risk-return determines the performance of a mutual fund scheme. As risk is commensurate with return, therefore, providing maximum return on the investment made within the acceptable associated risk level helps in demarcating the better performers from the laggards.

\section{Objectives}

Indian mutual fund industry is featured by a plethora of mutual fund schemes consisting of varying portfolio mix, investment objectives and expertise of professional fund management. For the small investor, choosing a suitable one is a complex decision. This present study has the objective of finding out the necessary facts regarding performance of selected growth-oriented open-ended schemes, which can benefit the investors and fund managers.

The specific objectives of the study are:

i) To measure the return earned by the sample mutual funds schemes and compare against the market portfolio returns to distinguish the performers from the laggards. ii) To find out those mutual fund schemes offering the advantages of diversification along with adequate systematic risk compared to market beta risk.

iii) To analyze the excess return per unit of risk evidenced by mutual fund schemes belonging to public sector and private sector, and to draw comparisons.

\section{Literature Review}

In this paper, an attempt has been made to study the performance of selected schemes of mutual funds based on risk-return relationship. For this purpose, apart from standard measure like mean return, beta and coefficient of determination, the time-tested models of mutual funds performance evaluation given by Sharpe, Treynor and Jensen have also been applied.

Early study on mutual funds included the several works of Jensen (1968), Sharpe (1966), and Treynor (1965) who used the capital asset pricing model (CAPM) to compare risk-adjusted returns of funds with that of a benchmark market portfolio. The findings of Sharpe and Jensen demonstrated that mutual funds under-perform market indexes and suggest that the returns were not sufficient to compensate investors for the diverse mutual fund charges. Friend, Brown, Herman and Vickers did a systematic study on mutual funds considering 152 funds with data period 1953-1958 and created Standard and Poor's indexes of five securities, with the elements by their representation in the mutual fund sample. Friends and Vickers (1965) concluded that mutual funds on the whole have not performed superior to random portfolio. Friend et al. (1970) in their study on mutual funds found that there is a negative correlation between fund performance and management expense measure. McDonald (1974) examined the relationship between the stated fund objectives and their risks-return attributes and concluded that on an average, the fund managers 
appeared to keep their portfolios within the stated risk. Ippolito (1989) concludes that mutual funds on an aggregate offer superior returns, but they are offset by expenses and load charges. Barua et al. (1991) evaluated the performance of Master Share during the period 1987-1991 using Sharpe, Jensen and Treynor measure and concluded that the fund performed better than the market, but not so well as compared to the Capital market Line. The mutual fund study by Gupta and Sehgal (1997) showed that out of sample of 80 schemes, income-growth schemes were the best performers and consistently out-performed the market index. Regarding consistency between measures and fund objectives, the relationship between fund objectives and betas is inconsistent with expectations. Sethu (1999) conducted a study examining 18 open-ended growth schemes during 1985-1999 and found that majority of the funds showed negative returns and no fund exhibited any ability to time the market. Gupta (2000) has examined the investment performance of Indian mutual funds using weekly Net Asset Value (NAV) data and found that the schemes have shown a mixed performance during 1994-1999.

In the Indian context, very few studies have compared the performance of the mutual fund schemes of private sector and public sector that paves the rationale of current study.

\section{Data and Sources of Study}

The period of study is form 1996-97 to 2008-09 (13 years). Six Private Sector Mutual Funds and Three Public sector Mutual funds, aggregately accounted for 23 Open-ended Growth-Oriented (equity-based) Mutual Fund Schemes have been selected for this study (Table-1). An open-ended fund is one that is available for subscription throughout the year. These do not have a fixed maturity. Investors can conveniently buy and sell units at NAV related prices. These schemes have been selected on the basis of regular data availability and launched during April 1996 until March 2009.
Daily NAV data have been used for the Schemes and the daily closing prices for the benchmark market index (NSE Nifty) have been used. The Primary sources of data have been Economic Times Investment Bureau and the official website of National Stock Exchange (www.nse-india.com).

\begin{tabular}{|l|l|}
\hline Private Mutual Funds & Public Mutual Funds \\
\hline Birla Sunlife (2 schemes) & LIC ( 3 Schemes) \\
Deutsche (2 Schemes) & SBI ( 3 Schemes) \\
DSP Merill Lynch (3 Schemes) & UTI ( 3 Schemes) \\
Franklin Templeton (3 Schemes) \\
HDFC (2 Schemes) \\
Prudential ICICI (2 Schemes) \\
\hline 6 Mutual Funds (14 Schemes) & 3 Mutual Funds (9 Schemes) \\
\hline Table -1: List of 9 Mitival Funds and 23 Schemes used in the Study \\
\hline
\end{tabular}

\section{Research Methodology}

The various measures of risk, return and portfolio performance used in the present study are presented below:

\subsection{Measures of Return}

The returns are computed on the basis of the NAVS of the different schemes and returns in the market index are calculated on basis of NSE Nifty on the respective date.

Portfolio or fund's return is calculated by using equation 1 as given below:

$R_{t}=\frac{\left(N A V_{t}-N A V_{t \cdot 1}\right)}{N A V_{t \cdot 1}}$

Where, $\mathrm{NAV}_{\mathrm{t}}$ \& $\mathrm{NAV}_{t-1}$ are net assets values for time period t and $t-1$ respectively.

Mean return of mutual fund scheme is calculated by using equation 2 as given below:

$$
\overline{\mathrm{R}}_{\mathrm{f}}=\prod_{t=1}^{n} \frac{R_{t t}}{n}
$$

Where $n$ is the total number of time period studied. 
Market return is given by equation 3 :

$R_{m t}=\frac{\left(I_{t}-I_{t-1}\right)}{I_{t .1}}$

Where $I_{1}$ and $I_{t \cdot 1}$ are value of benchmark market indices on period $t$ and $t-1$ respectively.

Therefore, mean return for the market portfolio is given by equation 4 as shown below:

$\overline{\mathrm{R}}_{m}=\square_{t=1}^{n} \frac{R_{m t}}{n}$

Where $n$ is the total number of time period studied. NSE Nifty consisting of 50 leading scrip listed in National Stock Exchange (NSE) has been taken as a proxy for market index. And the weekly yields on 91-day Treasury bills have been used as risk free rate of return $\left(R_{f}\right)$ in the study.

\subsection{Measures of Risk}

The risk is calculated on the basis of week-end NAVs. The following measures of risks associated with mutual funds have been used for the study:

i) Beta $(\beta)$ - results fund's volatility as regard market index measuring the extent of co-movement of fund with that of the benchmark index.

ii) Standard Deviation $(\sigma)$ - results fund's volatility or variation from the average expected return over a certain period.

iii) Co-efficient of Determination $\left(R^{2}\right)$-results the extent to which the movement in the fund can be explained by corresponding benchmark index (here, NSE Nifty).

\subsection{Risk-Return Relationship Models}

For evaluating the performance of mutual funds, the risk-return relation models given by Sharpe (1966), Treynor (1965) and Jensen (1968) have been applied in the study in addition to the measures listed above.
5.3.1 Sharpe Ratio: The Sharpe measure provides the reward to volatility trade-off. It is the ratio of the fund portfolio's average excess return divided by the standard deviation of returns as represented by equation 5 below:

Sharpe measure $=\frac{\left(A R_{p}-A R_{f}\right)}{\sigma_{p}} \ldots \ldots \ldots$ (eq. 5) Where $A R_{p}$ represents average return on mutual fund portfolio over the sample period, $A_{\mathrm{f}}$ represents average risk free return over the sample period, and $\delta_{p}$ represents standard deviation of excess returns over the sample period.

5.3.2 Treynor Ratio: The Treynor measure is similar to the Sharpe ratio except that it defines reward (average excess return) as a ratio of the CAPM beta risk and shown in equation 6 below:

Treynor measure $=\frac{\left(\mathrm{AR}_{\mathrm{p}}-\mathrm{AR}_{\mathrm{f}}\right)}{\beta_{\mathrm{p}}} \ldots \ldots \ldots$ (eq. 6) Where $\beta_{p}$ represents beta risk value for the mutual fund portfolio.

5.3.3 Jensen Alpha: The Jensen alpha measure is the intercept form the Sharpe-Litner CAPM regression of portfolio excess returns on the market portfolio excess returns over the sample period as defined below in equation form (eq. 7):

$\mathrm{R}_{\mathrm{pt}}-\mathrm{R}_{\mathrm{ft}}=\beta_{\mathrm{p}}\left(\mathrm{R}_{\mathrm{mt}}-\mathrm{R}_{\mathrm{ft}}\right)+\varepsilon$

Where $R_{p t}$ is the mutual fund portfolio return in period $t, R_{\mathrm{ft}}$ is the risk free return in period $t, R_{n u}$ is the return on the market portfolio in period $t$ and $\varepsilon$ is the error term or residual value.

\section{Empirical Findings and Discussion}

\subsection{Return Earned by the Schemes}

Table-2 depicts the return earned by schemes against corresponding market return since the inception date of scheme till March 2009. Return for both the scheme and the market has been calculated form the NAV and daily index value (S\&P NSE Nifty) respectively. 
All the 3 schemes of Franklin Templeton i.e., Balanced, Bluechip and Prima Plus among private sector, and the 3 schemes of UTI i.e., Dynamic Equity, India Advantage Equity and Money Market among Public sector were the highest return-earning schemes as against corresponding market returns witnessing returns in the range of $0.33 \%$ to $0.47 \%$ and $0.17 \%$ to $0.29 \%$ respectively. Negative return was observed in 3 schemes namely. Birla-Gilt-plus Liquid, LIC-Equity and LIC-Index Sensex which also failed to beat the market, and thus were the worst performers. Out of the 23 schemes, 15 schemes (about $65 \%$ ) had mean returns above their corresponding market returns which are a fairly good indicator of mutual fund performance. Only the schemes of $L I C$ showed poor performance, while rest had average returns.

\subsection{Systematic Risk (Beta)}

The fourth column of Table-2 presents the systematic risk of the 23 mutual fund schemes. Beta values of higher that unity imply higher portfolio risk for the schemes than the market portfolio, and vice-versa. Five schemes namely, Birla-Gilt-plus Liquid (1.0323), Birla-Asset Allocation Aggressive (1.0915), LIC-Equity (1.0143), LIC-Index Sensex (1.0215) and UTI-Money Market (1.0023) were found to be more risky (beta>1.0) than the market.

\begin{tabular}{|l|c|c|c|c|}
\hline \multicolumn{1}{|c|}{ Name of Scheme } & $\begin{array}{c}\text { Scheme } \\
\text { Return }\end{array}$ & $\begin{array}{c}\text { Market } \\
\text { Return }\end{array}$ & Beta & $\mathbf{R}^{2}$ \\
\hline Birla Sunlife - Gilt-plus Liquid & -.0021 & -.0017 & 1.0323 & 0.325 \\
Birla Sunlife - Asset Allocation Aggressive & .0014 & .0015 & 1.0915 & 0.492 \\
Detusche - Alpha Equity & .0007 & .0009 & 0.8142 & 0.431 \\
Deutsche - Dynamic Equity Reg. & .0140 & .0011 & 0.7911 & 0.493 \\
DSP Merill - Balanced & .0010 & .0007 & 0.9827 & 0.662 \\
DSP Merill - India TIGER Fund & .0037 & .0021 & 0.8814 & 0.678 \\
DSP Merill - Top 100 Equity & .0019 & .0013 & 0.8927 & 0.754 \\
Franklin Templeton-Balanced & .0033 & .0017 & 0.9913 & 0.692 \\
Franklin Templeton - Bluechip & .0047 & .0016 & 0.9421 & 0.714 \\
Franklin Templeton - Prima Plus & .0041 & .0011 & 0.8132 & 0.729 \\
HDFC - Capital Builder & .0010 & .0014 & 0.7314 & 0.481 \\
HDFC - Gilt Short Term & .0019 & .0027 & 0.7419 & 0.581 \\
LIC - Equity & -.0008 & .0029 & 1.0143 & 0.232 \\
LIC - Index Sensex & -.0051 & .0031 & 1.0215 & 0.249 \\
LIC - Short Term Plan & .0005 & .0016 & 0.9192 & 0.330 \\
Prudential ICICI-Balanced & .0004 & .0001 & 0.8929 & 0.417 \\
Prudential ICICI - Gilt Treasury & .0005 & .0030 & 0.7947 & 0.465 \\
SBI - Magnum Index & .0009 & .0008 & 0.9245 & 0.786 \\
SBI - Magnum Balanced & .0031 & .0020 & 0.8133 & 0.610 \\
SBI - Magnum Gilt & .0021 & .0014 & 0.8428 & 0.625 \\
UTI- Dynamic Equity & .0017 & .0011 & 0.9122 & 0.703 \\
UTI- India Advantage Equity & .0029 & .0015 & 0.8945 & 0.714 \\
UTI-Money Market & .0024 & .0013 & 1.0023 & 0.697 \\
\hline
\end{tabular}


Table-2: Mean Return, Beta and Co-efficient of Determination

Remaining 28 schemes had beta in the range of 0.800 to 0.995 except HDFC-Capital Builder (0.7314), HDFC-Gilt Short Term (0.7419) and Prudential $1 \mathrm{ClCl}-$ Gilt Treasury $(0.7947)$ holding portfolio that were least risk among the lot. In private sector, schemes of DSP Merill and Franklin Templeton were those having adequately risky portfolios well below the market risk, while in public sector the same phenomenon was observed in the 3 schemes of SBI.

\subsection{Co-efficient of Determination}

The last column of Table-2 shows the values of co-efficient of determination for the 23 schemes considered for the purpose of this study, when measured with the market index, NSE Nifty. High value of $R^{2}$ shows higher diversification of the schemes portfolio that can easily contain the market variability. The highest value was found in SBI-Magnum index (0.786), followed by DSP Merill-Top 100 Equity (0.754) and Franklin Templeton-Prima Plus (0.729) which indicates that these schemes have reasonably exploited the diversification strategy for forming their portfolio. Lower values of as witnessed in schemes of Birla Sunlife (less than 0.50) and Detusche $(<0.50)$ among private sector and LIC in public sector $(<0.35)$ suggest that these are inadequately diversified. The schemes of these 3 Mutual funds were also observed to have low mean returns with most of them failing to beat the market returns as shown in second and third column of Table-2. Thus it may be safely concluded that inadequate diversification of mutual fund schemes correlated with below-market returns.

Simple mean returns or measures of systematic risk as discussed above do not highlight the combined effect of both portfolio risk and returns. Thus, for meaningful evaluation of mutual fund schemes, risk-return relationship has been analyzed by using different measures of performance as given by Sharpe, Tryenor and Jensen models.

\subsection{Sharpe Ratio Measure}

Table-3 depicts the values of Sharpe ratio for the schemes and the market index. It calculates excess returns earned over risk-free return $\left(R_{f}\right)$ per unit of risk i.e., per unit of standard deviation. Positive values of schemes indicate better performance. Higher positive values of Sharpe ratio found in Detusche-Alpha Equity (1.840), Deutsche-Dynamic Equity Reg. (1.781), DSP Merrill-Top 100 Equity (1.771) among the private sector, and SBI-Magnum Index (1.694), SBI-Magnum Balanced (1.923), SBI-Magnum Gilt (2.189), UTI-Dynamic Equity (1.552), UTI-India Advantage Equity (1.300) and UTI-Money Market (1.341) among public sector shows existence of adequate returns as against the level of risk involved. Thus, the investors of these schemes have been rewarded well on their invested money. These schemes were also those which have out-performed the market index which further strengthens above conclusion.

11 schemes ( $48 \%$ ) have failed to beat the market Sharpe ratio and also have shown negative values. The worst performers are the 3 schemes of DSP Merrill Lynch (negative values and /or less than market Sharpe ratio) and the 3 schemes of LIC namely, LIC-Equity (-0.733), LIC-Index Sensex $(-0.841)$ and LIC-Short Term Plan (-0.433).

Although the 3 schemes of Franklin Templeton namely Balanced, Bluechip and PrimaPlus had negative Sharpe values, these schemes had higher values than their corresponding values of market index which goes to show the better performance of Franklin Templeton in a falling market. On the whole, the performance has been a mixed one with SBI and UTI being the best in public sector and Detusche taking the glory in private sector.

\subsection{Treynor Ratio Measure}

This measures the excess return earned over risk-free return per unit of systematic risk i.e., beta. 
The fourth and fifth column of Table -3 presents the Treynor ratio values for the schemes and the market portfolio respectively. Here, the major observations mirror the similar finding as in Sharpe ratio. The only exception being the 2 schemes of Prudential ICICl namely, Balanced (-0.031) and Gilt Treasury $(-0.027)$ out-performing the market portfolio while in Sharpe measure these were under-performers as against the market. This is primarily due to lower values of beta for these schemes as shown in fourth column of Table-2.
The highest Treynor ratio was found in SBI-Magnum Gilt (0.154) followed by SBI-Magnum Balanced (0.097), SBI-Magnum Index (0.084) and UTI-Dynamic Equity (0.073). The least values of Treynor ratio was witnessed in DSP Merill-Balanced $(-0.093)$, followed by LIC-Index Sensex $(-.092)$ and LIC-Equity (-.084). 13 schemes (about $57 \%$ ) showed positive values for Treynor ratio while 15 schemes (about $65 \%$ ) out-performing the market portfolio values of Treynor ratio.

\begin{tabular}{|c|c|c|c|c|c|}
\hline \multirow{2}{*}{ Name of Scheme } & \multicolumn{2}{|c|}{$\begin{array}{c}\text { Sharpe } \\
\text { Ratio }\end{array}$} & \multicolumn{2}{|c|}{$\begin{array}{c}\text { Treynor } \\
\text { Ratio }\end{array}$} & \multirow{2}{*}{ Jensen } \\
\hline & Scheme & Market & Scheme & Market & \\
\hline Birla Sunlife - Gilt-plus Liquid & 0.894 & 1.273 & .033 & .047 & .001 \\
\hline Birla Sunlife - Asset Allocation Aggressive & 0.799 & 1.118 & .045 & .079 & .003 \\
\hline Detusche-Alpha Equity & 1.840 & 1.325 & .049 & .033 & -.012 \\
\hline Deutsche - Dynamic Equity Reg. & 1.781 & 1.259 & .037 & .024 & -.014 \\
\hline DSP Merill - Balanced & -0.673 & -0.433 & -.093 & -.058 & .009 \\
\hline DSP Merill - India TIGER Fund & -0.844 & -0.723 & -.072 & -.067 & .014 \\
\hline DSP Merill - Top 100 Equity & 1.771 & 1.826 & .084 & .092 & .018 \\
\hline Franklin Templeton-Balanced & -1.347 & -1.449 & -.017 & -.022 & .007 \\
\hline Franklin Templeton - Bluechip & -1.507 & -1.818 & -.031 & -.053 & .005 \\
\hline Franklin Templeton - Prima Plus & -1.602 & -1.934 & -.043 & -.061 & .002 \\
\hline HDFC - Capital Builder & 0.934 & 0.993 & -.077 & .089 & -.011 \\
\hline HDFC - Gilt Short Term & 0.847 & 1.243 & .076 & .098 & -.004 \\
\hline LIC - Equity & -0.733 & -0.507 & -.084 & -.057 & -.004 \\
\hline LIC-Index Sensex & -0.841 & -0.615 & -.092 & -.062 & -.001 \\
\hline LIC - Short Term Plan & -0.433 & -0.317 & -.042 & -.035 & -.005 \\
\hline Prudential $\mid \mathrm{ClCl}$ - Balanced & -0.217 & -0.143 & -.031 & -.037 & .004 \\
\hline Prudential IClCl - Gilt Treasury & -0.119 & -0.107 & -.027 & -.022 & .002 \\
\hline SBI - Magnum Index & 1.694 & 1.443 & .084 & .073 & .011 \\
\hline SBI-Magnum Balanced & 1.923 & 1.334 & .097 & .081 & .017 \\
\hline SBI - Magnum Gilt & 2.189 & 1.430 & .154 & .094 & .006 \\
\hline UTI - Dynamic Equity & 1.552 & 1.211 & .073 & .055 & .021 \\
\hline UTI-India Advantage Equity & 1.300 & 1.128 & .056 & .053 & .008 \\
\hline UTI-Money Market & 1.341 & 1.098 & .058 & .041 & .014 \\
\hline
\end{tabular}

Table-3: Sharpe Ratio, Treynor Ratio and Jensen Alpha measures of the Mutual Fund Schemes 


\subsection{Jensen Alpha Measure}

The last column of Table-3 shows the Jensen's Alpha values for the 23 selected open-ended growth-oriented Mutual funds schemes. It is the regression of excess return of the scheme (dependent variable) with excess return of the market (independent variable). Higher Alpha values indicate better performance. Among the public sector, higher alpha was fond with UTI-Dynamic Equity (.021) followed by SBI-Magnum Balanced (.017) and UTI-Money Market (.014), while in private sector higher alpha measures was evidenced in the 3 schemes of DSP Merill Lynch namely, Top 100 Equity (.018), India TIGER Fund (.014) and Balanced (.009). Positive but negligible (<0.004) alpha values was recorded in Birla Sunlife namely Gilt-plus Liquid (.0001) and Asset Allocation Aggressive (.0003).

Only 7 schemes $(30 \%)$ showed negative alpha values which indicate the failure on part of their funds managers to forecast security prices in time for taking better investment decisions. While LIC failed to have positive alpha value in public sector, negative values was shown in schemes of Detusche and HDFC in private sector.

\section{Concluding Remarks}

Table-4 presents the performance of the mutual funds classified as private sector and public sector, in summarized form showing various parameters of performance. On the basis of returns, UTI mutual fund schemes and Franklin Templeton schemes have performed excellent in public and private sector respectively. Much of this is due to these schemes having portfolio of equities with high risk (high beta risk). On the other hand, LIC, Birla SunLife and HDFC schemes have failed to satisfy their investors in terms of returns in spite of taking higher risk.

On the basis of Sharpe ratio, Deutsche, Franklin Templeton, Prudential ICICI (in private sector) and SBI and UTI (in public sector) mutual funds have out-performed the market portfolio with positive values. These funds (except Deutsche and Prudential $\mathrm{ICICl}$ ) are also obsenved to have high $\mathrm{R}^{2}$ values (Coefficient of determination) indicating better diversification of the fund portfolio. The remaining 4 mutual funds witnessed negative values and also had Sharpe ratio below that of the market. The conclusion remained more or less similar with regard to Treynor measure except HDFC mutual fund turning out to beat the market as out-performer with positive values. Jensen Alpha measure had mixed responses in private sector funds, while in public sector only UTI and SBI managed to relatively high alpha values indicating better performance. 


\begin{tabular}{|c|c|c|c|c|c|c|c|}
\hline \multicolumn{2}{|c|}{ Mutual Fund Scheme } & Return & Beta (Risk) & $\begin{array}{c}\text { Sharpe } \\
\text { Ratio }\end{array}$ & $\begin{array}{l}\text { Treyor } \\
\text { Ratio }\end{array}$ & $\begin{array}{l}\text { Jensen } \\
\text { Alpha }\end{array}$ & $\mathrm{R}^{2}$ \\
\hline \multirow{6}{*}{$\begin{array}{l}\text { Private } \\
\text { Sector }\end{array}$} & Birla Sunlife & Poor & High & $\begin{array}{l}\text { Positive } \\
\text { Under } \\
\text { Performer }\end{array}$ & $\begin{array}{l}\text { Positive } \\
\text { Under } \\
\text { Performer }\end{array}$ & $\begin{array}{c}\text { Positive } \\
\text { Very } \\
\text { Low }\end{array}$ & $\begin{array}{l}\text { Very } \\
\text { Low }\end{array}$ \\
\hline & Deutsche & Moderate & Low & $\begin{array}{l}\text { Positive } \\
\text { Over" } \\
\text { Performer }\end{array}$ & $\begin{array}{l}\text { Positive } \\
\text { Over } \\
\text { Performer }\end{array}$ & $\begin{array}{l}\text { Negative } \\
\text { Moderate }\end{array}$ & Low \\
\hline & $\begin{array}{c}\text { DSP } \\
\text { Merill Lynch }\end{array}$ & Good & High & $\begin{array}{l}\text { Negative } \\
\text { Under } \\
\text { Performer }\end{array}$ & $\begin{array}{l}\text { Negative } \\
\text { Under } \\
\text { Performer }\end{array}$ & $\begin{array}{c}\text { Positive } \\
\text { Relatively } \\
\text { High }\end{array}$ & High \\
\hline & $\begin{array}{l}\text { Franklin } \\
\text { Templeton }\end{array}$ & Excellent & High & $\begin{array}{l}\text { Negative } \\
\text { Over } \\
\text { Performer }\end{array}$ & $\begin{array}{l}\text { Negative } \\
\text { Over } \\
\text { Performer }\end{array}$ & $\begin{array}{l}\text { Positive } \\
\text { Low }\end{array}$ & High \\
\hline & HDFC & Poor & Low & $\begin{array}{l}\text { Positive } \\
\text { Under } \\
\text { Performer }\end{array}$ & $\begin{array}{l}\text { Positive } \\
\text { Over } \\
\text { Performer }\end{array}$ & $\begin{array}{l}\text { Negative } \\
\text { Mixed }\end{array}$ & Low \\
\hline & $\begin{array}{l}\text { Prudential } \\
\qquad \mathrm{ICICl}\end{array}$ & Moderate & Low & $\begin{array}{l}\text { Negative } \\
\text { Over } \\
\text { Performer }\end{array}$ & $\begin{array}{c}\text { Negative } \\
\text { Over } \\
\text { Performer }\end{array}$ & $\begin{array}{l}\text { Postive } \\
\text { Very Low }\end{array}$ & Low \\
\hline \multirow{3}{*}{$\begin{array}{l}\text { Public } \\
\text { Sector }\end{array}$} & LIC & Poor & High & $\begin{array}{l}\text { Negative } \\
\text { Under } \\
\text { Performer }\end{array}$ & $\begin{array}{l}\text { Negative } \\
\text { Under } \\
\text { Performer }\end{array}$ & $\begin{array}{c}\text { Negative } \\
\text { Low }\end{array}$ & $\begin{array}{l}\text { Very } \\
\text { Low }\end{array}$ \\
\hline & SBI & Good & Low & $\begin{array}{l}\text { Postive } \\
\text { Over } \\
\text { Performer }\end{array}$ & $\begin{array}{l}\text { Postive } \\
\text { Over } \\
\text { Performer }\end{array}$ & $\begin{array}{c}\text { Positive } \\
\text { Relatively } \\
\text { High }\end{array}$ & High \\
\hline & UTI & Excellent & High & $\begin{array}{l}\text { Postive } \\
\text { Over } \\
\text { Performer }\end{array}$ & $\begin{array}{l}\text { Postive } \\
\text { Over } \\
\text { Performer }\end{array}$ & $\begin{array}{c}\text { Positive } \\
\text { Relatively } \\
\text { High }\end{array}$ & High \\
\hline
\end{tabular}

Table-4: Overall Performance of the Selected Mutual Funds

Under performer denotes situation where the Scheme's Specific Performance is lower than that of the Market;

"Over Performer denotes situation where the Scheme's Specific Performance is higher than that of the Market.

The overall analysis finds Franklin Templeton and UTI being the best performers, and Birla SunLife, HDFC and LIC mutual funds showing poor below-average performance when measured against the risk-return relationship models and measures. One of the lacunas of this study is that only open-ended growth-oriented schemes have been analyzed for the sample mutual funds. Future research may attempt to investigate and compare the close-ended schemes with open-ended and also the debt schemes with equity based growth oriented schemes. 


\section{REFERENCES}

1. Barua, S. K., Raghunathan, V. and Verma, J. R. (1991). Master Share: A Bonanza for Large Investors. Vikalpa, 29-34.

2. Friend, I., Blume, M. and Crockett, J. (1970). Mutual Funds and Other Institutional Investors: A New Perspective, McGraw Hill Book Company.

3. Friend, I. and Vickers, D. (1965). Portfolio Selection and Investment Performance. The Journal of Finance, 20(3), 391-415.

4. Gupta, A. (2000). Market Timing Abilities of Indian Mutual Fund Managers: An Empirical Study. The ICFAI Journal of Applied Finance, 6(2), 47-60.

5. Ippolito, R. A. (1993). On Studies of Mutual Fund Performance 1962-1991. Financial Analyst Journal, 43.

6. Jensen, M. C. (1968). The Performance of Mutual Funds 1945-64. Journal of Finance, 23(2), 389-416.

7. McDonald, J. G. (1974). Objectives and Performance of Mutual Funds 1960-1967. Journal of Financial and Quantative Analysis, 311-333.

8. Sethu, G. (1999). The Mutual Fund Puzzle, A paper presented at UTI-ICM, December, 23-24.

9. Sharpe, W. F. (1966). Mutual Fund Performance. Journal of Business, 30(1), 119-138.

10. Treynor, J. L. (1965). How to Rate Management of Investment Funds. Harvard Business Review, 43(1), 63-75. 